\title{
Scheduling of Periodic Maintainance for Chemicals and Pharmaceuticals Equipments to Ensure Safety Operations
}

\author{
S. Robin, G. Santhoshkumar, R. Velanganni
}

\begin{abstract}
The significance of mechanical wellbeing was acknowledged on the grounds that consistently a great many modern mishaps happen which result in either demise or impermanent and lasting disablement of the workers and include a decent measure of cost, for example, coming about because of waste worker hours, machine hours, and so on. Wellbeing is fundamentally the duty of the administration. This duty should lay on the shoulder of all units of the executives, for example, generation administrator, faculty supervisor, support engineer, wellbeing official. Each association ought to plan and execute a wellbeing strategy.
\end{abstract}

Keywords: disablement, administration

\section{INTRODUCTION}

Security in basic terms implies opportunity from the event or danger of damage or misfortune. Mechanical security or representative wellbeing alludes to the assurance of laborers from the peril of modern mishaps.

In the present focused world numerous association are receiving advance innovation. It has the two benefits and negative marks. Expanding advances includes high hazard, where the subject of security emerges. The life of modern specialist is brimming with hazard. Consistently lakhs of workers are harmed in manufacturing plants, mines and so on. The fundamental purposes behind such exercises are because of either perilous act or dangerous condition.

Today businesses are committed to give their representatives a safe and verified workplace.

The primary motivation behind viable wellbeing program in associations is to forestall business related wounds and mishaps.

\section{SAFETY IN INDUSTRY}

The advanced wellbeing development began around 1912 with the primary helpful Safety Congress and the association of the National Safety Council in U.S.A.

Wellbeing is preceding security. As per this idea, the present Factories Act guarantees a few wellbeing measures.

Revised Manuscript Received on December 30, 2019.

S. Robin, Assistant professor, Department Of Science \& Humanities, Bharath Institute of Higher Education and Research ,Chennai, India. Email:

G. Santhoshkumar, Assistant professor, Department Of Science \& Humanities, Bharath Institute of Higher Education and Research ,Chennai, India. .Email santhoshravi671026@gmail.com

R. Velanganni, Assistant professor, Department Of Science \& Humanities, Bharath Institute of Higher Education and Research ,Chennai, India..Email velangannijose78516@gmail.com

The significance of mechanical wellbeing was acknowledged on the grounds that consistently a great many modern mishaps happen which result in either demise or impermanent and lasting disablement of the workers and include a decent measure of cost, for example, coming about because of waste worker hours, machine hours, and so on.

Wellbeing is fundamentally the duty of the administration. This duty should lay on the shoulder of all units of the executives, for example, generation administrator, faculty supervisor, support engineer, wellbeing official. Each association ought to plan and execute a wellbeing strategy.[1]-[4]

\section{OBJECTIVES OF THE STUDY}

\section{A. PRIMARY OBJECTIVE:}

To Study on "Safety Measures of Employees with reference to Orchid chemicals and pharmaceuticals Itd".,

\section{B. SECONDARY OBJECTIVE:}

- To analyze the effectiveness of safety measures provided by the organization.

- To ascertain the need and expectation of the employees regarding their safety measures in the organization.

- To study the adequacy of wellbeing preparing projects gave to the workers.

- To break down the degree of complaint taking care of system with respect to security issues gave by the association.

\section{SCOPE OF THE STUDY}

- The study on representatives observation on viability on wellbeing measures and workplace is solely directed for Orchid Chemicals and pharmaceuticals Limited, directed to the employee's.

- This issue is of considerable interest to the modern industry today, as it concerns the needs of both management and workers and has an impact on the productivity and satisfaction of workers.[5]-[10]

\section{RESEARCH METHODOLOGY}

Business research can be defined as a structured, systematic, data-based, critical, objective, scientific study or investigation of a particular problem undertaken with a view to getting answers or solutions to it. 


\section{Scheduling of Periodic Maintainance for Chemicals and Pharmaceuticals Equipments to Ensure Safety}

Operations

\section{A. RESEARCH DESIGN}

The research is concise in nature. The purpose of the descriptive analysis is to provide the author with a profile or to explain important aspects of phenomena of importance from a human, institutional, industry-oriented or other perspective[11]-[15]

\section{RESULTS \& DISCUSSION}

\section{A. PRIMARY DATA}

Primary data refer to information collected first-hand by the author on variables of interest for the particular purpose of the study.

\section{B. SECONDARY DATA}

Secondary data refers to information collected from existing sources. Secondary information relating to this analysis were obtained from business manuals, books, journals, magazines and websites.[15]-[20]

\section{RESEARCH INSTRUMENT}

Structured Questionnaire is presented, and includes both open and opened questions.

\section{SAMPLING METHODS}

The sampling method adopted in the research is the sampling probability. In particular, "Hierarchical proportional sampling" Here the universe is divided into strata on the basis of the division.[21]-[25]

\section{E. ANALYSIS TOOLS}

\section{CORRELATION}

Connection examination manages the relationship between at least two factors. It doesn't educate anything concerning circumstances and logical results relationship. Relationship is characterized in two kinds as:

Positive and Negative Correlation.

SPEARMAN Correlation strategy, it additionally can be said as Rank Correlation. It is characterized by the image ' $r$ '

$6 \sum \mathrm{di}^{2}$

$\mathrm{R}=1-\cdots$

$\mathrm{N}\left(\mathrm{n}^{2}-1\right)$

Relationship worth will consistently lie somewhere in the range of +1 and -1 . At the point when $r=1$, it appears there is ideal positive relationship between's factors. At the point when $r=0$, There is no connection

\section{ANALYSIS USING CORRELATION}

\section{Correlation between satisfaction level and} communication about the safety measures.

Let $\mathrm{X}$ be the satisfaction level

\begin{tabular}{|c|c|c|c|}
\hline S.No & Particular & $\begin{array}{c}\text { No.of } \\
\text { respondents }\end{array}$ & $\begin{array}{c}\text { Percentage no.of } \\
\text { respondents }\end{array}$ \\
\hline $\mathbf{l}$. & Highly satisfied & 57 & $47 \%$ \\
\hline $\mathbf{2}$. & Satisfied & 29 & $33 \%$ \\
\hline $\mathbf{3}$. & Neutral & 30 & $17 \%$ \\
\hline $\mathbf{4 .}$ & Dissatisfied & 3 & $2 \%$ \\
\hline $\mathbf{5}$. & Highly dissatisfied & 1 & $1 \%$ \\
\hline & Total & $\mathbf{1 2 0}$ & $\mathbf{1 0 0} \%$ \\
\hline
\end{tabular}

Let $\mathrm{Y}$ be the communication about the safety measures

\begin{tabular}{|c|c|c|c|}
\hline S.No & particular & $\begin{array}{c}\text { No.of } \\
\text { respondents }\end{array}$ & $\begin{array}{l}\text { Percentage no.of } \\
\text { respondents }\end{array}$ \\
\hline 1. & Highly satisfied & 45 & $82 \%$ \\
\hline 2. & Satisfied & 51 & $8 \%$ \\
\hline 3. & Neutral & 17 & $7 \%$ \\
\hline 4. & Dissatisfied & 2 & $2 \%$ \\
\hline \multirow[t]{2}{*}{5.} & Highly dissatisfied & 5 & $1 \%$ \\
\hline & Total & 120 & $100 \%$ \\
\hline
\end{tabular}

THE TABLE SHOWING CORRELATION BETWEEN SATISFACTION LEVEL AND COMMUNICATION ABOUT THE SAFETY MEASURES.

\begin{tabular}{|c|c|c|c|c|c|}
\hline $\mathbf{X}$ & Rank X & $\mathbf{Y}$ & Rank Y & $\mathbf{D}=\mathbf{X}-\mathbf{Y}$ & $\mathbf{D}^{2}$ \\
\hline $\mathbf{5 7}$ & $\mathbf{1}$ & $\mathbf{4 5}$ & $\mathbf{2}$ & -1 & $\mathbf{1}$ \\
\hline 29 & $\mathbf{3}$ & $\mathbf{5 1}$ & $\mathbf{l}$ & $\mathbf{2}$ & 4 \\
\hline 30 & $\mathbf{2}$ & $\mathbf{1 7}$ & $\mathbf{3}$ & -1 & 1 \\
\hline 3 & 4 & $\mathbf{2}$ & $\mathbf{5}$ & -1 & 1 \\
\hline $\mathbf{1}$ & $\mathbf{5}$ & $\mathbf{5}$ & 4 & 1 & 1 \\
\hline Total & & & & & 8 \\
\hline
\end{tabular}

$6 \Gamma \lambda: 2$

\begin{tabular}{|c|c|c|c|c|c|}
\hline $\mathbf{X}$ & Rank X & $\mathbf{Y}$ & Rank Y & $\mathbf{D}=\mathbf{X}-\mathbf{Y}$ & $\mathbf{D}^{2}$ \\
\hline 57 & $\mathbf{1}$ & 45 & 2 & -1 & 1 \\
\hline 29 & 3 & 51 & 1 & 2 & 4 \\
\hline 30 & 2 & 17 & 3 & -1 & 1 \\
\hline 3 & 4 & 2 & 5 & -1 & 1 \\
\hline 1 & 5 & 5 & 4 & 1 & 1 \\
\hline Total & & & & & 8 \\
\hline
\end{tabular}

Formula:

$$
\mathbf{R}=\quad 1-\quad \begin{gathered}
6 \sum \mathrm{di}^{2} \\
-\mathbf{N}\left(\mathrm{n}^{2}-1\right)
\end{gathered}
$$

$$
1-\quad 5\left(5^{2}-1\right)
$$

\section{INTERPRETATION}

$$
\mathbf{R}=\mathbf{0 . 3}
$$

So the correlation is 0.3 so there exist a strong positive correlation between satisfaction level and communication about the safety measures.

\section{FINDINGS}

- $42 \%$ of workers were happy with the safety measures offered to them. 
- $57 \%$ of workers were pleased with the organization's efforts to ensure a health issue.65\% of the respondent are satisfied with the retraining given to employees who act unsafely.

- $67 \%$ of the employees feel that the organization always take immediate action to investigate incidents.

- $67 \%$ of the employees are satisfied with the active role in safety issues.

- $75 \%$ of the employees are satisfied with the scheduled meeting regarding safety.

\section{SUGGESTIONS}

$\checkmark$ The majority of employees were pleased with the security provision given to them.

$\checkmark$ PARY Many of the workers are not very well aware of this, so they should be inspired every year by rivalry on the national day of health. Security activities can often be carried out to raise awareness among employees about security.

$\checkmark$ Many of the employees are expecting training regarding the chemicals which is highly inflammable and toxic.

\section{CONCLUSION}

The country's industrial progress depends on its committed workforce. Efficiency in work can only be accomplished if staff feel safe in their working environment and have also been equipped with certain safety measures.

The examination has uncovered the view of representatives as to wellbeing measures and workplace. The consequence of this investigation shows that lion's share of the representatives see the present endeavors taken by orchid synthetic compounds and pharmaceuticals limited on wellbeing measures and workplace is good yet there are a few components which should be thought by the organization which is recommended by the specialist to guarantee hundred rate security and harmonious workplace which thus in improve the effectiveness and certainty of the representatives.

\section{REFERENCES}

1. Vasanthi, S. \& Rabiyathul Basariya, S. 2019, "Influence of value analysis and cross training in industry", International Journal of Engineering and Advanced Technology, vol. 8, no. 6, pp. 1810-1811.

2. Velvizhi, R., Sri Gowtham, S. \& Jeya Priya, D. 2019, "Examination of early feedbacks for effective product retailing on E-commerce websites", International Journal of Engineering and Advanced Technology, vol. 8, no. 6 Special Issue 2, pp. 703-706.

3. Anuradha, C., Pothumani, S. \& Kavitha, R. 2019, "A novel method towards E-commerce", International Journal of Engineering and Advanced Technology, vol. 8, no. 6 Special Issue 2, pp. 535-538.

4. Thomas, J. \& Rabiyathul Basariya, S. 2019, "A study on the issues of financial ratio analysis", Indian Journal of Public Health Research and Development, vol. 10, no. 3, pp. 1079-1081.

5. Ramachandran, S. \& Rabiyathul Basariya, S. 2019, "Online marketing - study on customer satisfaction and relationship", Indian Journal of Public Health Research and Development, vol. 10, no. 3 , pp. 1072-1078.

6. Priya, R., Vinothini, G. \& Cor Jesu, C.D. 2019, "The mentor-protégé relationship for professional growth", Journal of Advanced Research in Dynamical and Control Systems, vol. 11, no. 9 Special Issue, pp. 1110-1119.

7. Jannifer Rani, N., Bina Pani, S. \& Nimisha, N.S. 2019, "A study on money back polices available in LIC", Journal of Advanced Research in Dynamical and Control Systems, vol. 11, no. 9 Special Issue, pp. 833-839.

8. Saillaja, V., Jhansi Rani, K. \& Catherine, R. 2019, "Global marketing management planning and organization", Journal of Advanced
Research in Dynamical and Control Systems, vol. 11, no. 9 Special Issue, pp. 489-493.

9. Saillaja, V., Jhansi Rani, K. \& Catherine, R. 2019, "The new phase of marketing information system", Journal of Advanced Research in Dynamical and Control Systems, vol. 11, no. 9 Special Issue, pp. 482-488.

10. Thoufiqulla \& Raju, D.V. 2019, "Perception of indian investor towards investment in mutual funds with special reference to mip funds", Journal of Advanced Research in Dynamical and Control Systems, vol. 11, no. 5, pp. 177-183.

11. Jasmine, K.R.M. \& Basariya, S.R. 2018, "A study on the customers benefits on mutual funds", International Journal of Civil Engineering and Technology, vol. 9, no. 4, pp. 45-48.

12. Vasanthi, S. \& Basariya, S.R. 2019, "Pros and cons of on the job training versus off the job training", International Journal of Scientific and Technology Research, vol. 8, no. 10, pp. 671-674.

13. Pavithra, J. \& Ganesan, M. 2016, "A study on awareness and impact of micro-financial schemes", International Journal of Applied Business and Economic Research, vol. 14, no. 8, pp. 5449-5460.

14. Pavithra, J., Dilli Babu, P. \& Ambuli, T.V. 2014, "A study on budgetary control at Maruti Service Masters, Chennai", International Journal of Applied Business and Economic Research, vol. 12, no. 2, pp. 151-161.

15. Gunaraja, T.M. \& Venkatrama Raju, D. 2018, "Determining factors of organisational climate with reference to leadership styles", International Journal of Mechanical Engineering and Technology, vol. 9, no. 9, pp. 1327-1332.

16. Gunaraja, T.M. \& Venkatrama Raju, D. 2018, "The role of job satisfaction and training of employees in determining organisational climate of a selected industry", International Journal of Civil Engineering and Technology, vol. 9, no. 8, pp. 1266-1269.

17. Aarathy, T.S. \& Raju, D.V. 2018, "Performance appraisal and its effects on employees with respect to it sector in Chennai city", International Journal of Civil Engineering and Technology, vol. 9, no. 6, pp. 1535-1538.

18. Aarathy, T.S. \& Raju, D.V. 2018, "Employee perception towards performance appraisal system in IT sector", International Journal of Mechanical Engineering and Technology, vol. 9, no. 5, pp. 131-135.

19. Porselvi, W., Jublee, D. \& Sivanesan, G. 2018, "A study on factors influencing adoption of technology and innovation in banking industry, tamilnadu, India", International Journal of Mechanical Engineering and Technology, vol. 9, no. 5, pp. 789-800.

20. Akessa, G.M. and Dhufera, A.G., 2015. Factors That Influences Students Academic Performance: A Case of Rift Valley University, Jimma, Ethiopia. Journal of Education and Practice, 6(22), pp.55-63.

21. Miller, G. and Shih, C.C., 1999. A faculty assessment of the academic rigor of on-and off-campus courses in agriculture. Journal of Agricultural Education, 40, pp.57-65.

22. Tsinidou, M., Gerogiannis, V. and Fitsilis, P., 2010. Evaluation of the factors that determine quality in higher education: an empirical study. Quality Assurance in education, 18(3), pp.227-244.

23. Farooq, M.S., Chaudhry, A.H., Shafiq, M. and Berhanu, G., 2011 Factors affecting students' quality of academic performance: a case of secondary school level. Journal of quality and technology management, 7(2), pp.1-14.

24. Fitsilis, P., Gerogiannis, V. and Anthopoulos, L., 2014. Ontologies for software project management: a review. Journal of Software Engineering and Applications, 7(13), p.1096.

25. Adams, J.D. and Jaffe, A.B., 1996. Bounding the effects of R\&D: an investigation using matched establishment-firm data(No. w5544). National bureau of economic research.

\section{AUTHORS PROFILE}

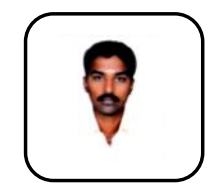

S. Robin, Assistant professor, Department Of Science \& Humanities, Bharath Institute of Higher Education and Research ,Chennai, India 
Scheduling of Periodic Maintainance for Chemicals and Pharmaceuticals Equipments to Ensure Safety Operations

G. Santhoshkumar, Assistant professor, Department Of Science \& Humanities, Bharath, Institute of Higher Education and Research ,Chennai, India. .

R. Velanganni, Assistant professor, Department Of Science \& Humanities, Bharath Institute of Higher Education and Research ,Chennai, India 